УДК 336-026.564:336.71

DOI: https://doi.org/10.32847/business-navigator.65-20

Тарасова O.B.

кандидат економічних наук, доцент, доцент кафедри обліку та аудиту

Одеська національна академія харчових технологій

Tarasova Olena

Candidate of Economic Sciences, Associate Professor, Associate Professor of the Department of Accounting and Auditing Odessa National Academy of Food Technologies

\title{
ПРОБЛЕМИ ЗАБЕЗПЕЧЕННЯ ФІНАНСОВОЇ СТІЙКОСТІ БАНКІВСЬКОЇ СИСТЕМИ
}

Тарасова О.В. Проблеми забезпечення фінансової стійкості банківської системи. У статті досліджуються проблеми забезпечення фінансової стійкості банківського сектору, яка відіграє надзвичайно важливу роль у функціонуванні фінансової системи держави. Обгрунтовано роль стабільності банківської системи для забезпечення умов економічного зростання. Зазначено, що саме фінансова стійкість кожної банківської установи є передумовою стабільного функціонування всієї банківської системи. Проаналізовано тенденції у формуванні депозитної бази комерційних банків України та диспропорції у сфері залучення банківських ресурсів. Сформульовано пріоритети грошово-кредитної політики та основні завдання, вирішення яких дасть змогу активізувати кредитування реального сектору економіки. Розроблено теоретичні та практичні рекомендації щодо вдосконалення банківського кредитування, підвищення прибутковості банківської системи та рівня капіталізації українських банків.

Ключові слова: фінансова стійкість, фінансова система, фінансовий ринок, банківська система, депозити, кредити, кредитно-грошова політика.

Тарасова Е.В. Проблемы обеспечения финансовой устойчивости банковской системы. В статье исследуются проблемы обеспечения финансовой устойчивости банковского сектора, которая играет чрезвычайно важную роль в функционировании финансовой системы государства. Обоснована роль стабильности банковской системы для обеспечения условий экономического роста. Отмечено, что именно финансовая устойчивость каждого банковского учреждения является предпосылкой стабильного функционирования всей банковской системы. Проанализированы тенденции формирования депозитной базы коммерческих банков Украины и диспропорции в сфере привлечения банковских ресурсов. Сформулированы приоритеты денежно-кредитной политики и основные задачи, решение которых позволит активизировать кредитование реального сектора экономики. Разработаны теоретические и практические рекомендации по усовершенствованию банковского кредитования, повышению прибыльности банковской системы и уровня капитализации украинских банков.

Ключевые слова: финансовая устойчивость, финансовая система, финансовый рынок, банковская система, депозиты, кредиты, кредитно-денежная политика.

Tarasova Olena. Problems of ensuring the financial sustainability of the banking system. The article explores the problems of ensuring the financial sustainability of the banking sector, which plays a very important role in the functioning of the financial system of the state. The role of the stability of the banking system in ensuring conditions of economic growth is justified. It is noted that it is the financial stability of each banking institution that is a prerequisite for the stable functioning of the entire banking system. It is emphasized that since the financial stability of the banking system is influenced by a large number of internal and external factors, for the effective functioning of the banking system of the country must be ready for any challenges to the macro and microenvironment. The main problems of the banking system in modern conditions should be considered the reduction of deposits of the population, deterioration of the quality of the loan portfolio, significant devaluation of the hryvnia, high inflation rates, loss-making of a significant number of banking institutions. It was concluded that the banking system of Ukraine feels a significant dependence on the funds of depositors - individuals, and therefore on factors that affect their behavior in the financial market. Trends of formation of deposit base of commercial banks of Ukraine and imbalances in the sphere of attraction of banking resources were analyzed. The growth of bank deposits of the population is slow, negative changes in their structure are observed. The share of deposits of individuals after the 2014 crisis has become significantly more volatile and risky in terms of financial stability. The increase in lending is complicated by the presence of large portfolios of problem loans, as a result of which there are a number of tasks to increase the efficiency of the loan portfolio, which should ensure a compromise of profitability, liquidity and credit risk acceptable to the bank. The priorities of monetary policy and the main tasks are formulated, the solution 
of which will allow to intensify lending to the real sector of the economy. Theoretical and practical recommendations have been developed to improve bank lending, increase the profitability of the banking system and capitalize Ukrainian banks.

Key words: financial stability, financial system, financial market, banking system, deposits, loans, monetary policy.

Постановка проблеми. Фінансова стійкість економіки будь-якої країни значною мірою визначається стабільністю іï банківської системи. При цьому на фінансову стійкість банківської системи впливає велика кількість внутрішніх і зовнішніх чинників, а тому для ефективного функціонування банківська система країни має бути готова до будь-яких викликів макро- та мікросередовища. На сучасному етапі розвитку економіки України особливої актуальності набуває проблема забезпечення фінансової стійкості банківської системи, яка залежить від фінансового стану кожного окремого банку та його здатності ефективно розвиватися. Саме фінансова стійкість кожної банківської установи $є$ передумовою стабільного функціонування всієї банківської системи.

Аналіз останніх досліджень і публікацій. Дослідження теоретичних та практичних аспектів функціонування банківської системи знайшли своє відображення у працях вітчизняних і зарубіжних учених, серед яких: О.С. Врублевський [1], Н.О. Кожель [2], В.Д. Лагутін [3], О.П. Орлюк [4], Я.А. Жаліло [7], Л.Г. Шемаєва [7], Н.Я. Юрків [7] та ін. Разом із цим, високо оцінюючи результати цих досліджень, слід констатувати, що проблеми забезпечення фінансової стійкості банківської системи досліджено недостатньо і потребують особливої уваги.

Формулювання завдання дослідження. Метою статті є дослідження сучасного стану банківської системи України та проблем забезпечення іії фінансової стійкості.

Виклад основного матеріалу дослідження. Банківська система України поступово відновлюється після кризи 2014-2015 рр., коли перед нею постала низка проблем, основними серед яких можна вважати: скорочення вкладів населення, погіршення якості кредитного портфелю, значну девальвацію гривні, високі темпи інфляції, збитковість значної кількості банківських установ тощо [5, с. 90].

Зростання банківських вкладів населення відбувається повільними темпами. Частка коштів фізичних осіб у структурі сукупних депозитів дорівнює $50,6 \%$, а частка коштів приватних нефінансових корпорацій лише $28,5 \%$. У зв'язку із цим банківська система відчуває суттєву залежність від коштів вкладників - фізичних осіб, а отже, й від чинників, які впливають на їхню поведінку на фінансовому ринку.

За даними НБУ, обсяг гривневих депозитів фізичних осіб станом на 01.01.2019 становив 289,4 млрд грн, що перевищує на 31,6 млрд грн рівень початку 2014 p. (257,8 млрд грн на 01.01.2014). Ситуація щодо валютних депозитів виглядає гірше. На 01.01.2019 вони становили 8,7 млрд дол., що в 2,6 рази менше, ніж у 2014 р. (23,0 млрд дол.). Динаміка депозитів фізичних осіб протягом 2019 р. була позитивною. Обсяг гривневих вкладів населення становив 339,2 млрд грн на 01.01.2020, що перевищило на 49,8 млрд грн, або на
17\%, рівень початку 2019 р. Валютні вклади фізичних осіб за 2019 р. зросли на 1,3 млрд дол., або на 15\%, до 10,0 млрд дол. Протягом 2020 р. динаміка депозитів фізичних осіб також була позитивною. Гривневі вклади населення зросли на 94,2 млрд грн, із 339168 млрд грн на 01.01.2020 до 433417 на 01.01.2021 [6]. При цьому треба зауважити, що в реальному вимірі, тобто враховуючи індекс споживчих цін (ICЦ), депозити населення в національній валюті значно зменшилися порівняно 3 докризовим періодом (рис. 1).

Аналіз банківських депозитів фізичних осіб за строками повернення показує, що вклади до одного року - найбільш популярний в Україні вид депозитів. Ця негативна тенденція зберігається протягом 2014-2019 рр., коли спостерігається збільшення частки вкладів до одного року і зменшення частки довгострокових депозитів (понад два роки). Вклади на вимогу це гроші, які можуть бути зняті з рахунків вкладниками у будь-який момент без попередження. Вони є нестабільними залишками на рахунках i тому не можуть бути джерелом для довгострокового кредитування реального сектору економіки. Досліджуючи динаміку цих депозитів в останні роки, можна стверджувати, що відбувається стабільне зростання частки залишків на вимогу у загальній сумі вкладів [5, с. 92]. Частка депозитів на вимогу у 2020 р. становить $41,7 \%$, на початок 2014 р. цей показник становив $20 \%$, на початок 2015 p. - 24\%, на початок 2016 р. - 27\%, на початок 2017 р. - 29\%, на початок 2018 р. - 34\%, на середину 2018 р. - 38\%. Таким чином, у цей період спостерігаються негативні зміни у структурі банківських вкладів населення, частка депозитів фізичних осіб після кризи 2014 р. стала значно більш волатильною та ризиковою 3 погляду фінансової стабільності.

На стан фінансової стійкості банківської системи негативно впливають також чинники, пов'язані 3 діяльністю Фонду гарантування вкладів фізичних осіб (ФГВФО). Так, важливими чинниками є обмеженість ресурсів ФГВФО, а також відсутність інструментів прибуткового розміщення власних коштів, оскільки Фонд має право інвестувати власні кошти лише в облігації внутрішньої державної позики України (ОВДП), але не має вільних ресурсів для їх придбання. До того ж сума гарантованого відшкодування, яка не змінювалася 32012 р., становить 200 тис грн (еквівалент близько 6 тис євро), тоді як у країнах ЄС сума гарантованого відшкодування становить 100 тис євро. У зв'язку із цим, на нашу думку, необхідно переглянути в бік збільшення суму гарантованого відшкодування вкладів.

Поступово відновлюється банківське кредитування. Обсяг кредитів, наданих українськими банками нефінансовим корпораціям, зменшився впродовж 2014-2015 pр. на 115,6 млрд грн і лише у 2019 р. досягнув рівня 2013 р. Упродовж 2019 р. відбулося погіршення ситуації у сфері корпоративного кредитування (табл. 1). 


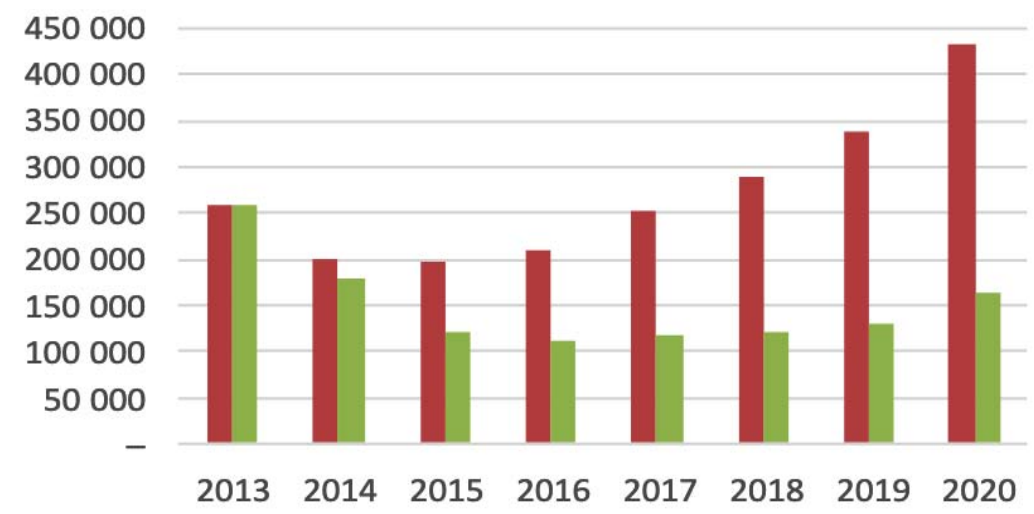

Гривневі депозити домогосподарств, в т.ч. ФОП

Депозити в цінах 2013 р.

Рис. 1. Гривневі депозити домогосподарств, у т. ч. 3 урахуванням ІСЦ, млн грн

Джерело: сформовано за даними [6; 7]

Кредити нефінансовим корпораціям у національній валюті скоротилися 3 464,0 до 426,5 млрд грн, або на $8 \%$, кредити в іноземній валюті зменшилися з 14,3 до 13,4 млрд дол. США, або на 6\%. У 2020 р. ці негативні тенденції залишилися без змін, що позначилося на скороченні як гривневих корпоративних кредитів (на 11,0 млрд грн), так і валютних (на 1,9 млрд дол. США).

За строками кредитування спостерігається тенденція до скорочення довгострокових кредитів. На 01.01.2020 частка довгострокових кредитів (зі строком погашення понад п'ять років) становила лише $18 \%$ кредитів, наданих нефінансовим корпораціям, а на 01.10.2020 вона скоротилася до позначки 16,9\%. При цьому спостерігаються диспропорції у строковій структурі банківських депозитів і кредитів, що виявляється у значному перевищенні частки довгострокових кредитів порівняно з часткою довгострокових депозитів, яка становила у 2019 р. лише 2,3\%.

Ресурси банків України активно інвестуються в облігації внутрішньої державної позики та депозитні сертифікати НБУ (табл. 2). Державні цінні папери вважаються найбільш надійними та ліквідними, що зумовлює зростання інвестицій у ОВДП як інструмент для довгострокових вкладень.

Негативі обставини (тимчасова окупація Криму, збройний конфлікт на Сході України, скорочення промислового виробництва, зайнятості, девальвація гривні) викликали збитковість банківського сектору України протягом 2014-2017 рр. Із 2018 р. почалося відновлення прибуткової діяльності банків. Показники капіталізації банківської системи є недостатніми для вирішення завдань, які стоять перед нею, і в першу чергу - відновлення кредитування реального сектору економіки.

Нарощування кредитування є головною метою банківського бізнесу, досягнення якої у сучасних умовах ускладнено наявністю великих портфелів проблемних кредитів. У зв'язку із цим постає низка завдань щодо підвищення ефективності кредитного портфеля, що має забезпечити компроміс дохідності, ліквідності та кредитного ризику, прийнятного для банку.

Висновки. Отже, важливою передумовою забезпечення фінансової стійкості банківської системи є активізація кредитування. У зв'язку із цим основними завданнями грошово-кредитної політики НБУ мають стати:

- оздоровлення проблемного кредитного портфеля банків та подальше зростання його обсягу;

- зміна пріоритетів банківського інвестування із вкладень у державні цінні папери на кредитування реального сектору економіки;

- відновлення та подальше зростання обсягу банківських депозитів;

Динаміка кредитів українських банків нефінансовим корпораціям у 2019-2020 рр.

\begin{tabular}{|c|c|c|c|c|c|c|c|c|}
\hline & 01.01.2019 & 01.04.2019 & 01.07.2019 & 01.10 .2019 & 01.01 .2020 & 01.04.2020 & 01.07 .2020 & 01.10 .2020 \\
\hline $\begin{array}{l}\text { Кредити } \\
\text { нефінансовим } \\
\text { корпораціям в } \\
\text { національній валюті, } \\
\text { млн грн }\end{array}$ & 464023 & 453347 & 444295 & 441773 & 426514 & 433682 & 419841 & 415548 \\
\hline $\begin{array}{l}\text { Кредити } \\
\text { нефінансовим } \\
\text { корпораціям в } \\
\text { іноземній валюті, } \\
\text { млн дол. США } \\
\end{array}$ & 14292 & 14064 & 13768 & 13395 & 13431 & 13172 & 12809 & 11575 \\
\hline Разом, екв. млн грн & 859740 & 836014 & 804711 & 765907 & 744648 & 797637 & 761426 & 743246 \\
\hline
\end{tabular}

Джерело: сформовано за даними [6; 7] 
Інвестиції банківської системи України у державні цінні папери

Таблиця 2 \begin{tabular}{|c|c|c|c|c|c|c|c|}
\hline 01.01.2019 & 01.04.2019 & 01.07.2019 & 01.10.2019 & $\mathbf{0 1 . 0 1 . 2 0 2 0}$ & $\mathbf{0 1 . 0 4 . 2 0 2 0}$ & $\mathbf{0 1 . 0 7 . 2 0 2 0}$ & $\mathbf{0 1 . 1 0 . 2 0 2 0}$ \\
\hline
\end{tabular}

\begin{tabular}{|l|c|c|c|c|c|c|c|c|}
\hline & $\mathbf{0 1 . 0 1 . 2 0 1 9}$ & $\mathbf{0 1 . 0 4 . 2 0 1 9}$ & $\mathbf{0 1 . 0 7 . 2 0 1 9}$ & $\mathbf{0 1 . 1 0 . 2 0 1 9}$ & $\mathbf{0 1 . 0 1 . 2 0 2 0}$ & $\mathbf{0 1 . 0 4 . 2 0 2 0}$ & $\mathbf{0 1 . 0 7 . 2 0 2 0}$ & $\mathbf{0 1 . 1 0 . 2 0 2 0}$ \\
\hline $\begin{array}{l}\text { ОВДП у портфелі } \\
\text { банків, млн грн }\end{array}$ & 410828 & 402366 & 382419 & 380775 & 366603 & 388347 & 483901 & 509326 \\
\hline $\begin{array}{l}\text { Сертифікати, НБУ } \\
\text { у портфелі банків, } \\
\text { млн грн }\end{array}$ & 62112 & 58042 & 45465 & 60052 & 152221 & 116162 & 105322 & 122767 \\
\hline $\begin{array}{l}\text { Державні цінні папери } \\
\text { у портфелі банків, } \\
\text { разом, млн грн }\end{array}$ & 472940 & 460408 & 427884 & 440827 & 518824 & 504509 & 589223 & 632093 \\
\hline $\begin{array}{l}\text { ОВДП у портфелі НБУ, } \\
\text { млн грн }\end{array}$ & 362319 & 354427 & 350332 & 350377 & 345440 & 334129 & 332888 & 334231 \\
\hline $\begin{array}{l}\text { ОВДП, придбані } \\
\text { банківською } \\
\text { системою, разом }\end{array}$ & 773147 & 756793 & 732751 & 731152 & 712043 & 722476 & 816789 & 843557 \\
\hline
\end{tabular}

Джерело: сформовано за даними [6; 7]

- проведення стимулюючої монетарної політики та надання банкам більшої гнучкості в управлінні власною ліквідністю;

- посилення ролі облікової ставки як орієнтира для здешевлення кредитних ресурсів для реального сектору економіки;
- залучення державних банків до кредитування реалізації пріоритетних цілей розвитку;

- наближення банківського законодавства щодо гарантування вкладів до вимог ЄС.

Подальші дослідження будуть спрямовані на попередження кредитних ризиків банківської системи.

\section{Список використаних джерел:}

1. Врублевський О.С. Громадянин і банк: депозитні операції. Київ : Леста, 2005. 44 с.

2. Кожель Н.О. Оцінка факторів впливу на процес формування та реалізації депозитної політики банку. Проблеми $i$ перспективи розвитку банківської системи України. 2005. № 12. С. 223-234.

3. Лагутін В.Д. Кредитування: теорія і практика : навчальний посібник. Київ : Знання КОО, 2002. 215 с.

4. Орлюк О.П. Фінансове право : навчальний посібник. Київ : Юрінком Інтер, 2003. 528 с.

5. Тарасова О.В. Проблеми формування депозитної бази комерційних банків України. Економіка харчової промисловості. 2019. Том 11. Вип. 2. С. 89-94.

6. Офіційне Інтернет-представництво Національного Банку України. URL: https://bank.gov.ua/ua/news/all/richniyzvit-natsionalnogo-banku-za-2020-rik-10-faktiv-pro-te-yak-zminilisya-ekonomika-ta-finansova-sistema-uprodovj-pershogoroku-pandemiyi (дата звернення: 17.05.2021).

7. Проблеми та перспективи зміцнення стійкості фінансової системи України : аналітична доповідь / Л.Г. Шемаєва та ін. ; за наук. ред. Я.А. Жаліла. Київ : НІСД, 2021. 104 с. URL: https://niss.gov.ua/sites/default/files/2021-02/e_book_ zhalilo_2-sait-2_0.pdf (дата звернення: 17.05.2021).

\section{References:}

1. Vrublevskyi O.S. (2005) Hromadianyn i bank: depozytni operatsii [Citizen and bank: deposit transactions]. Kyiv: TOV «IKTs Lesta». (in Ukrainian)

2. Kozhel N.O. (2005) Otsinka faktoriv vplyvu na protses formuvannia ta realizatsii depozytnoi polityky banku [Assessment of factors of influence on the process of formation and implementation of the bank's deposit policy]. Problemy i perspektyvy rozvytku bankivskoi systemy Ukrainy, no. 12, pp. 223-234.

3. Lahutin V.D. (2002) Kredytuvannia: teoriia i praktyka [Lending: theory and practice]. Kyiv: Tov-vo «Znannia», KOO (in Ukrainian)

4. Orliuk O.P. (2003) Finansove pravo [Financial law]. Kyiv: Yurinkom Inter. (in Ukrainian)

5. Tarasova O.V. (2019) Problemy formuvannia depozytnoi bazy komertsiinykh bankiv Ukrainy [Problems of formation of the deposit base of commercial banks of Ukraine]. Ekonomika kharchovoi promyslovosti, vol. 11, no. 2, pp. 89-94.

6. Ofitsiine internet-predstavnytstvo Natsionalnoho Banku Ukrainy. Available at: https://bank.gov.ua/ua/news/all/richniyzvit-natsionalnogo-banku-za-2020-rik-10-faktiv-pro-te-yak-zminilisya-ekonomika-ta-finansova-sistema-uprodovj-pershogoroku-pandemiyi (accessed 17 May 2021).

7. Zhalilo Ya.A. (ed.) (2021) Problemy ta perspektyvy zmitsnennia stiikosti finansovoi systemy Ukrainy [Problems and prospects of strengthening the stability of the financial system of Ukraine]. Kyiv: NISD. Available at: https://niss.gov.ua/sites/ default/files/2021-02/e_book_zhalilo_2-sait-2_0.pdf (accessed 17 May 2021). 